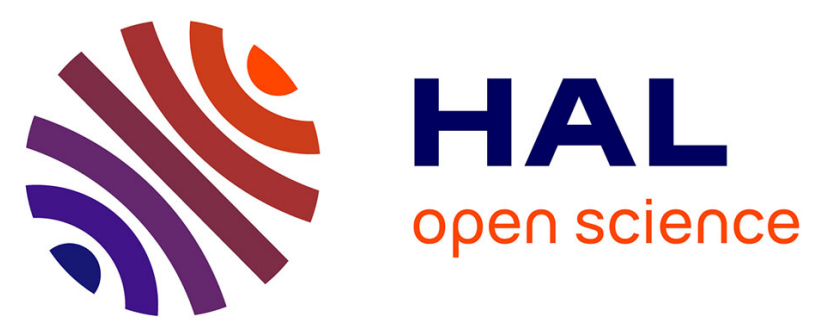

\title{
Influence of the intrinsic characteristics of mortars on biofouling by Klebsormidium flaccidum
}

\author{
Thu Hien Tran, Alexandre Govin, René Guyonnet, Philippe Grosseau, \\ Christine Lors, Eric Garcia-Diaz, Denis Damidot, Olivier Devès, Bertrand \\ Ruot
}

\section{To cite this version:}

Thu Hien Tran, Alexandre Govin, René Guyonnet, Philippe Grosseau, Christine Lors, et al.. Influence of the intrinsic characteristics of mortars on biofouling by Klebsormidium flaccidum. International Biodeterioration and Biodegradation, 2012, 70, pp.31-39. 10.1016/j.ibiod.2011.10.017 . hal-00680295

\section{HAL Id: hal-00680295 \\ https://hal.science/hal-00680295}

Submitted on 19 Mar 2012

HAL is a multi-disciplinary open access archive for the deposit and dissemination of scientific research documents, whether they are published or not. The documents may come from teaching and research institutions in France or abroad, or from public or private research centers.
L'archive ouverte pluridisciplinaire HAL, est destinée au dépôt et à la diffusion de documents scientifiques de niveau recherche, publiés ou non, émanant des établissements d'enseignement et de recherche français ou étrangers, des laboratoires publics ou privés. 
Influence of the intrinsic characteristics of mortars on biofouling by Klebsormidium flaccidum

Thu Hien TRAN ${ }^{\mathrm{a}, \mathrm{b}, \mathrm{c}}$, Alexandre GOVIN ${ }^{\mathrm{a}}$, René GUYONNET ${ }^{\mathrm{a}}$, Philippe GROSSEAU ${ }^{\mathrm{a}}$, Christine LORS $^{\mathrm{b}, \mathrm{c}}$, Eric GARCIA-DIAZ ${ }^{\mathrm{d}}$, Denis DAMIDOT ${ }^{\mathrm{b}, \mathrm{c}}$, Olivier DEVES ${ }^{\mathrm{e}}$, Bertrand RUOT $^{\mathrm{e}}$

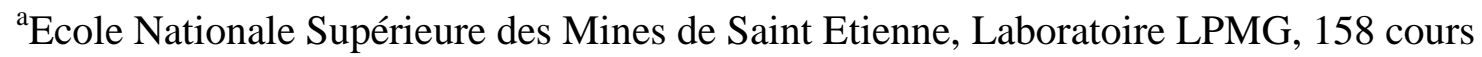
Fauriel, 42023 St-Etienne, France

${ }^{\mathrm{b}}$ Université Lille Nord de France, 1 bis Gerges Lefèvre, 59044 Lille, France

${ }^{c}$ EM Douai, LGCgE-MPE-GCE, 941 Rue Charles Bourseul, 59500 Douai, France

${ }^{\mathrm{d}}$ Ecole des Mines d'Alès, Centre de Recherche CMGD, 6 Avenue de Clavières, 30319 Alès, France

${ }^{\mathrm{e}}$ Université Paris Est, Centre Scientifique et Technique du Bâtiment, Département Enveloppe et Revêtements, 84 avenue Jean Jaurès, Champs-sur-Marne, 77447 Marne-la-Vallée, France *Corresponding author: govin@emse.fr

\begin{abstract}
The goal of this study was to elucidate the influence of the intrinsic properties of roughness, porosity, and surface $\mathrm{pH}$ on the susceptibility of mortars to biodegradation by phototrophic microorganisms. An accelerated fouling test was performed allowing a periodic sprinkling of an algae suspension on sample surfaces. The green alga Klebsormidium flaccidum was chosen due to its representativeness and facility in culturing. The biofouling of sample surfaces was evaluated by means of image analysis and color measurement. Two porosities, three roughnesses, and two surface pHs were examined. The colonization by algae of sample surfaces was not influenced by porosity because of the specific conditions of testing that led
\end{abstract}


to a constant high level of moistening of mortar samples. The roughness, in contrast, played an important role in biological colonization. A rougher surface facilitates the attachment of algal cells and so favors the extension of algae. The surface $\mathrm{pH}$ was the most important parameter. A lower surface $\mathrm{pH}$ accelerated considerably the development of algae on the samples surface.

Keywords:

Biofouling

Algae

Mortar

Porosity

Roughness

Surface $\mathrm{pH}$

\section{Introduction}

Rendering is a very common construction technique for masonry walls in France. Indeed, each year, 150 million $\mathrm{m}^{2}$ of facade are coated with industrial mortars, corresponding to 3.5 million tons of mortars. Fifty-five percent of this is used for new construction and the remainder is dedicated to renovation (SNMI, 2010). Exposed to weathering and affected by various factors such as rain, wind, sunlight, $\mathrm{CO}_{2}$, freezing/thawing cycles, and salt crystallization, rendered surfaces are progressively and inevitably subjected to biological colonization (Le Borgne, 1994; Hendry, 2001). 
The biofilms encountered on building facades are mainly green, black, or red stains, depending on the biological species. The main biological organisms identified are green algae and cyanobacteria, which pave the way for the implantation and growth of lichens, followed by bryophytes, pteridophytes, and finally spermatophytes (Wee and Lee, 1980; Grant, 1982; Ortega-Calvo et al., 1995; Tomaselli et al., 2000; Barberousse, 2006). The idea that algae could significantly degrade the structure of building materials remains debatable (Grant, 1982). However, stains, due to colonization by algae, clearly affect the aesthetics of the facade. Biological fouling represents a significant economic loss, due to the costs of maintenance and repair. If facades colonized by algae are untreated, environmental particles (dust, pollen, spores, oil- and coal-fired particles) might be entrapped within the entangled microbial mass, giving rise to complex crusts and patinas that are difficult to eliminate (SaizJimenez, 1995).

The biological colonization on building surfaces is dependent on both environment and substrate (John, 1988; Tomaselli et al., 2000; Barberousse, 2006).

Crispim et al. (2003) have shown that the composition and predominant phototroph species (cyanobacteria or algae) depend on the local climate (temperate or tropical). However, the most significant environmental factor controlling algal growth on building facades relates to the micro-climate (e.g., moisture, light) (Ariño et al., 1997). This can vary depending on inclination, aspect, exposure to shadow, distance from the ground, and internal climate of the building (e.g., temperature, wall thickness) (John, 1988). If moisture is high enough and if lighting and temperature conditions are suitable, colonization of the surface of new buildings can occur very quickly. Evidence of algal growths was reported by Wee and Lee (1980) on concrete walls of buildings from Singapore within 12 months after completion.

The substrate characteristics that contribute to biological colonization are both physical (roughness, porosity) and chemical (mineral composition, surface $\mathrm{pH}$ ) (Deruelle, 
1991; Ortega-Calvo et al., 1995; Tomaselli et al., 2000). All of these parameters are included in the term "bioreceptivity" defined by Guillitte (1995). Among them, the roughness seems to be the most important factor, according to several researchers (Darlington, 1981; Wee and Lee, 1980). Indeed, roughness favors the adhesion of microorganisms and also organic material blown by the wind or brought by water flow to the substrate. Furthermore, roughness affects the flow of water on the surface. Consequently, rough building facades are more subjected to the biofouling than smooth ones (Wee and Lee, 1980; Pietrini et al., 1985; Joshi and Mukudan, 1997; Tomaselli et al., 2000). The roughness also influences absorption of solar radiation. It was shown that for a given color, an increase in roughness generally leads to an increase of solar radiation absorption, and therefore, to an increased surface temperature. The amplitude of this phenomenon is more intense with light colors than with dark ones (Chevalier and Chevalier, 1991).

The total porosity and pore size distribution are factors to take into account. They influence the absorption and retention of water by the material and the capillary rise on part of walls in contact with the soil (Ohshima, 1999; Prieto and Silva, 2005; Miller et al., 2006, 2009). Therefore, the porous structure partially determines the water availability for the development of algae.

Other conditions being equal, colonization is known to be much slower on freshly built surfaces such as concrete and cement-based materials where the $\mathrm{pH}$ is initially higher than 11 even at the surface (Grant, 1982). With time, the combined action of water and atmospheric carbonation leads to a progressive decrease in $\mathrm{pH}$ of the building surface, which becomes low enough (about 9) to allow algal growth (John, 1988).

Nowadays, the means for preventing biofouling are the elimination of moisture sources (through the architecture or the environments near building facades) (Wee and Lee, 1980) and the use of water repellents or biocides. However, the first solution has a limited 
effectiveness. The second one is not durable and is restricted by environmental concerns. A third trend consists of developing coatings with intrinsic parameters unfavorable to the development of biological stains. A fourth trend is the use of metal strips, e.g., zinc and copper (Wessel, 2011). Identifying and quantifying the role of different intrinsic parameters of material on algal growth remain thus essential.

Some laboratory tests were carried out to study the role of roughness and porosity of mortars (Ohshima, 1999; Dubosc et al., 2001; Barberousse, 2006). But these studies only proposed a qualitative evaluation of the biofouling or compared very different materials. No work was devoted to a detailed kinetic study of colonization. Carbonated mortars using accelerated conditions, with a surface $\mathrm{pH}$ around 9, were used extensively in order to accelerate the biofouling test (Grant and Bravery, 1985; Escadeillas et al., 2007; Barberousse, 2006; De Muynck et al., 2009). However, no study quantifies the difference effect of these carbonated mortars and the ones kept in atmospheric conditions (called uncarbonated, $\mathrm{pH}>$ 11) on algal development.

In this study, the susceptibility of mortar to algal fouling was evaluated regarding the role of porosity, roughness, and surface $\mathrm{pH}$ by means of an accelerated test. This waterstreaming test was originally designed at ITECH (Lyon, France), and then improved in the thesis work of Barberousse (2006).

\section{Materials and methods}

\subsection{Set of materials}

The studied materials were made up of Portland cement CEM I 52.5 N (Holcim), siliceous sand (Sibelco DU 0.1/0.35), and calcareous filler (Omya). Table 1 gives the 
proportions of these constituents. The mortar was prepared with a water to cement ratio, $w / c$, (wt/wt) of 0.5 . In order to obtain a more porous mortar, the $w / c$ ratio was increased to 1 . Cellulose ether (hydroxylethyl methyl cellulose - HEMC) was added as admixture to thicken the mortar and thus avoid segregation.

For each mortar, three finishing methods were applied on the surface of samples during the setting. One method involved smoothing with a ruler and the two others scratching with sponges of two different roughnesses.

The mortar mixture was cast into $50 \times 50 \times 1 \mathrm{~cm}$ expanded polystyrene moulds and stored at $21 \pm 1^{\circ} \mathrm{C}$ and $95 \pm 5 \%$ relative humidity during 28 days for the preparation of uncarbonated mortars. Carbonated samples were stored for only 7 days before the carbonation step and plates were cut into $20 \times 8 \times 1 \mathrm{~cm}$ samples. The carbonation of the samples was achieved in a chamber under pure $\mathrm{CO}_{2}$, at $21 \pm 1^{\circ} \mathrm{C}$, and $65 \pm 5 \%$ relative humidity for 36 days. Each sample was labeled according to three codes. The first one is the $w / c$ ratio, the second one expresses the carbonation state, and the third corresponds to the roughness. For example, a sample labeled 05UC-R2, corresponds to an uncarbonated sample, carried out with a $w / c$ ratio equal to 0.5 , and with the intermediate level of roughness.

\subsection{Characterization of materials}

The pore size distribution and total porosity of materials was characterized using mercury intrusion porosimetry (Micromeritics Autopore IV 9400) (MIP). The results reported represent the average of values obtained for three samples that were dried beforehand by acetone. 
The surface roughness was measured using a CHR-150-L profilometer. The roughness was evaluated by the arithmetic average of the height $R_{a}$, the maximum height of peaks $R_{p}$, and the maximum depth of valleys $R_{v}$ (Gadelmawla et al., 2002).

The $\mathrm{pH}$ of surface mortar was measured by a surface electrode (WTW Sentix Sur). To ensure contact between the substrate and the $\mathrm{pH}$-electrode, the mortar surface was moistened.

\subsection{Origin and culture of the algae}

The accelerated test was conducted with the filamentous green algae Klebsormidium flaccidum. The strain (ALCP 749B) was obtained from the culture collection of microalgae at the Muséum National d'Histoire Naturelle (MNHN, Paris, France). This strain was selected because of its representativeness. It is indeed frequently isolated from samples taken on sites (John, 1988; Ortega-Calvo et al., 1995; Barberousse, 2006; Rindi et al., 2008). Moreover, this alga is easy to cultivate in the laboratory (Lokhorst, 1996).

The strain was grown in a batch culture under sterile conditions. This was carried out in a glass bottle containing $400 \mathrm{ml}$ of Bold's basal medium (BBM) (Barberousse, 2006). The light was provided by two neon lamps (OSRAM Fluora L36W/77) with a 12h/12h light/dark photoperiod. Air was provided by means of an air pump (Schego Optimal). The culture was shaken at $100 \mathrm{rpm}$ with a magnetic stirrer.

\subsection{Accelerated biofouling test}

The experimental device consisted of a $100 \times 50 \times 50 \mathrm{~cm}$ closed glass chamber placed in a dark room. At the start of the test, 501 of sterilized BBM and a controlled amount of the alga $K$. flaccidum were introduced into the chamber. The initial algae concentration was fixed 
to $4 \mathrm{mg}^{-1}$ of dry mass for every test. The concentration of algae was controlled by UV-Vis spectroscopy after calibration (abs=f(dry mass)). Moreover, the algae were always used at the same state in the growth phase (21 days of growth). This procedure aimed to ensure the same activity of algae for every test and minimize the latency time and thus the duration of the test. The suspension was maintained at $24^{\circ} \mathrm{C}$ by means of a thermo-regulator.

In this device, two rows of samples were placed back-to-back on a stainless-steel support inclined at $45^{\circ}$. This inclination has been used by several researchers (Dubosc et al., 2001; Barberousse, 2006; De Mynck et al., 2009) in order to promote the spread of algae. Each row of samples was equipped with a system composed of a stainless-steel tube $(10 \mathrm{~mm}$ in diameter drilled every $10 \mathrm{~mm}$ ) and two pumps (Rena Flow $650 \mathrm{BF}$ ). This device allowed a suspension of algae to flow on the top of each sample. The sprinkling period took place for 90 min every $12 \mathrm{~h}$. The amount of suspension received by each sample during one cycle was around $26 \pm 21 \mathrm{~h}^{-1}$. The system constituted a closed circuit and allowed placing a series of samples in the same chamber.

The light was provided by two neon lamps (OSRAM Fluora L30W/77) for $12 \mathrm{~h}$ /day and was set to start with the beginning of a sprinkling cycle.

In each test, 18 samples were placed in the chamber. Each formulation was tested in triplicate. Carbonated and uncarbonated samples were tested separately.

\subsection{Evaluation of biofouling}

Colorimetric measurements and image analysis were used in order to evaluate the intensity of the biofouling (Young, 1997; Grossi et al., 2003; De Muynck et al., 2009). Colorimetric measurements were carried out using a portable spectrophotometer (Konica Minolta CM-2600d) with an 8-mm aperture. On each specimen, thirty-six measurements were 
monitored and recorded at fixed positions spread over the whole surface of the sample. The data on $L^{*} a^{*} b^{*}$ color space were collected. The evolution of the color was calculated by the difference from the initial day of each color coordinate and by the color difference $\Delta E$, which is defined as follows: $\Delta E=\sqrt{\Delta L^{2}+\Delta a^{2}+\Delta b^{2}}$.

Concerning image analysis, the surface of each sample was digitized daily, by means of an office scanner (Epson Perfection V300). The numerical image obtained was a color image composed of the three channels R (red), G (green), and B (blue). To improve the detection of algae on the surface of the cementitious samples, the image was converted in the YIQ space. This color space is a linear combination of the R, G and B channels as follows (Pratt, 2001):

$$
\left[\begin{array}{l}
Y \\
I \\
Q
\end{array}\right]=\left[\begin{array}{ccc}
0.299 & 0.587 & 0.114 \\
0.596 & -0.274 & -0.321 \\
0.211 & -0.523 & 0.311
\end{array}\right] \times\left[\begin{array}{c}
R \\
G \\
B
\end{array}\right]
$$

$\mathrm{Y}, \mathrm{I}$, and Q correspond respectively to luminance, in-phase, and quadrature. This system is used in the standard NTSC analog TV. On the Q channel, the areas covered by algae and the areas of clean mortar were better distinguished. A threshold value of 10 in grey level was then chosen to segment the image and to quantify the surface colonized by algae. The conversion process allowed us to overcome the similarity observed in RGB color space between algal patches and dark slots caused by the rough relief. The extent of colonization versus time was given by the ratio of colonized area to total surface.

An example of image analysis of a carbonated specimen prepared with a $w / c$ ratio of 0.5 after 17 days of testing is shown on Fig. 1. Figure 1a shows the original picture obtained by digitization. Figure $1 \mathrm{~b}$ shows the $\mathrm{Q}$ band of Fig. 1a after converting it into YIQ color space. Figure 1c illustrates the segmentation between the fouled (red pixels) and the unfouled (black pixels) areas. 


\section{Results}

\subsection{Characterization of materials}

The total porosity of mortars is given in Table 2 . The porosity of uncarbonated mortar prepared with a $w / c$ ratio of 1 was more than two times higher than those of mortar prepared with a $w / c$ ratio of 0.5 . The increase in porosity is due to adding cellulose ether and to the increase in $w / c$ ratio. The carbonated mortar was less porous than the uncarbonated one. A reduction of $33 \%$ and $14 \%$ were observed for mortar prepared respectively with a $w / c$ of 0.5 and 1.

Figure 2 showed the pore size distribution of the mortar samples. For uncarbonated samples, the mortar prepared with a $w / c$ ratio of 0.5 had pores mainly around $0.05 \mu \mathrm{m}$ in diameter, whereas the pore size distribution of mortar prepared with a $w / c$ ratio of 1 was trimodal and distributed around $0.02 \mu \mathrm{m}, 0.06 \mu \mathrm{m}$, and $0.4 \mu \mathrm{m}$. The increase in the pore's volume between $0.06 \mu \mathrm{m}$ and $1 \mu \mathrm{m}$ was attributed to excess water $(w / c=1)$ and to the addition of cellulose ether (Pourchez et al., 2010). For carbonated samples, the mortar prepared with a $w / c$ ratio of 0.5 showed one pore distribution around $0.01 \mu \mathrm{m}$. For the mortar prepared with a $w / c$ ratio of 1 , it seems that the two smallest distributions were clogged and thus did not appear as open porosity. The carbonation reduces the volume and the entrance diameter of a pore, due to precipitation of calcium carbonate.

Table 3 shows the roughness values measured for the mortar mixed with a $w / c$ of 1 . The surface of the roughest mortar (R3) presented strong reliefs and a significant dispersion between samples. The $\mathrm{R}_{\mathrm{a}}$ value measured for these samples was four to six times higher than that of the mortars with the smallest roughness (R1). The mortar with intermediate roughness 
(R2) presented asperities having a size of the same order as that of the sand used $(\mathrm{D} 50=248$

$\mu \mathrm{m})$. For all other mortars made with a $w / c$ of 0.5 , three different surface roughnesses were also obtained. However, on the surface of the mortar prepared with a $w / c$ ratio of 1 and R1 roughness, the presence of holes due to air bubbles trapped during preparation was noticed. They were not present on the surface of mortar prepared with a $w / c$ ratio of 0.5 that did not contain CE.

The mortar samples were carbonated in their entire thickness. This was checked by depositing a phenolphthalein solution on a fracture surface of a sample. The discoloration of the phenolphthalein solution, on the entire surface, revealed a decrease in $\mathrm{pH}$, less than 9 , due to the carbonation of the sample. Two levels of surface $\mathrm{pH}$ were obtained: 11 and 9 for uncarbonated and carbonated mortars, respectively (Table 2). The surface $\mathrm{pH}$ of carbonated mortar prepared with a $w / c$ ratio of 0.5 was slightly higher than that of the other carbonated mortar made with a $w / c$ ratio of 1 . This phenomenon was probably due to the lower porosity inducing a lower rate of carbonation.

\subsection{Colonization of materials}

\subsubsection{General observations}

The images in Fig. 3 illustrate the algae fouling of specimens after different test durations. The colonization by $K$. flaccidum produced dense velvety mats formed by many entangled filaments, as noted by Rindi et al. (2008). The fouling of the sample surface was initiated by small spots of algae clinging to the surface. These spots appeared at preferred locations of the surface such as air bubble holes or asperities formed by the roughness. The extension of the fouling resulted in the proliferation of the first spots and in the adhesion of new ones. On the surface of the smoothest mortar (R1) and the intermediate rough mortar 
(R2), biological fouling was observed as streaks due to the flow of the suspension. This colonization process was often observed on building envelopes (Barberousse, 2006). On the surface of the roughest mortar (R3), the flow was affected by the roughness and thus fouling grew along it.

All the graphs show the mean value and standard deviation of three specimens. Good reproducibility and homogeneity were obtained. Indeed, the evolution of $\Delta E$ in different parts of surface of mortar 10C-R1 was quite similar (Fig. 4). The top, middle, and bottom represent three parts having the same area along the longitudinal direction. The edge and center represent two parts having the same area situated at the center and two sides in the transverse direction. These results were observed for all other samples in the test chamber.

\subsubsection{Influence of porosity}

Figure 5 shows the influence of $w / c$ ratio on the covered area versus time for the smoothest mortars. In spite of a significant difference in porosity between mortars of the two $w / c$ ratios, the colonization by algae was similar. For both carbonated samples, the colonization was nearly identical. It began at about 12 days of experimentation. Half of the surface of each sample was covered after 24 days. After 32 days, the two mortars were completely covered by algae. For the uncarbonated mortar, a modest difference was observed between the two mortars. The mortars mixed with a $w / c$ ratio of 1 seem to be colonized faster than those mixed with a $0.5 \mathrm{w} / \mathrm{c}$ ratio. This trend may be due to the defects present on the surface of the first, favoring the algae attachment. The colonization curves are all S-shaped.

\subsubsection{Influence of roughness}

Figure 6 represents the effect of roughness on the evolution of area covered by algae for uncarbonated and carbonated mortars elaborated with a $w / c$ ratio of 1 . It can be seen that 
the latency time on the smoother surface was longer than that on the rougher surface (for example 12 days for R1 against 8 days for R2 and 6 days for R3, carbonated mortar). The slopes of the curves show that the rate of colonization of the smoother surface was also lower than that of the rougher one. After 32 days, the entire surface of the smoothest carbonated mortar (R1) was covered, while it took 27 days for the carbonated mortar of intermediate roughness (R2) and 25 days for the roughest carbonated mortar (R3).

Figure 7 illustrates the relationship between the roughness and the time to colonize half of the surface. This time decreases as roughness increases. This influence is more amplified on the uncarbonated mortars than on the carbonated ones, with a nonlinear relationship.

\subsubsection{Influence of surface $\mathrm{pH}$}

Colonization of carbonated mortars started much earlier than colonization of uncarbonated ones. For the lowest roughness (R1), the carbonated mortars prepared with a $w / c$ ratio of 0.5 were colonized after 12 days, as opposed to 56 days for uncarbonated mortar (Fig. 5). Similarly, it took 12 days versus 30 days for mortar prepared with a $w / c$ ratio of 1 (Fig. 5). For the two tested $w / c$ ratios, the total colonization of carbonated mortars was achieved after 32 days, while it took 97 days for uncarbonated ones. The slope of the curves indicated a coverage rate of carbonated mortars significantly higher than that of uncarbonated ones. Similar results were observed by Shirakawa et al. (2003) on the colonization of mortars by fungi (C. sphaerospermum). Indeed, he showed that $\mathrm{pH}$ values below or close to 9 allowed the colonization of mortars by C. sphaerospermum, while $\mathrm{pH}$ close to, or higher than 10 , inhibited the fungal growth.

The leaching effect of sprinkling reduced the surface $\mathrm{pH}$ of carbonated mortar to about 8.5 after $1 \mathrm{wk}$, while it was 9.4 for the uncarbonated mortars (Fig. 8). The dissolution of 
alkaline oxides (sodium, potassium) and portlandite from mortar changed the $\mathrm{pH}$ of algae suspension to 8 and 9 , respectively, for carbonated samples and uncarbonated ones after $1 \mathrm{wk}$ (Fig. 9). Then, the $\mathrm{pH}$ remained constant. The alkaline medium constituted an extreme and poor condition for the algae. Ultrastructural changes in cells and a high proportion of dead cells were seen by Škaloud (2006). Adhesion and growth rate of the microorganism were influenced by $\mathrm{pH}$.

The most harmful effect to the algae seemed to occur as the $\mathrm{pH}$ increased. Indeed, the algae in the carbonated chamber were more abundant than in the uncarbonated one. However, almost all of them attached to the supports. The concentration of algal suspension was evaluated by the chlorophyll $a$ fluorescence measurement, which is much more sensitive than the dry mass or optical density (Babichenko et al., 2001). The excitation wavelength was 467 $\mathrm{nm}$; the emission wavelength was $685 \mathrm{~nm}$. The evolution of fluorescence intensity of the algal suspension with time appeared similar in two series of experiments carried out on the carbonated and uncarbonated samples (Fig. 10). A decline in fluorescent intensity was observed after 35 days for both experiments. This decrease in fluorescence intensity of the algal suspension could be due either to cell death or to an influence of the surroundings on the metabolic activity of the cells. This second point was previously observed by Naessens et al. (2000) with the glyphosate herbicide which decreased the chlorophyll turnover and, then, the fluorescence intensity.

\section{Discussion}

In numerous studies on stone, the porosity is seen as an important factor influencing the development of algae (Prieto and Silva, 2005; Miller et al., 2006, 2009). In laboratory tests simulating water runoff, Guillitte and Dressen (1995) and Barbarousse (2006) 
highlighted the fact that porous materials promote colonization by algae. By contrast, in the present study, the effect of porosity was not obvious. This was explained by the permanent water saturation of mortars in the condition tested. Indeed, the relative humidity in the chamber always remained around $100 \%$ during the period of darkness and around $80 \%$ in the daytime.

Roughness was shown to be an important parameter that favored colonization of cementitious materials by algae. This result is consistent with those of previous studies (Prieto and Silva, 2005; Miller et al., 2006, 2009). Indeed, the roughness provides numerous asperities that promote the attachment of algae dispersed by runoff. For filamentous algae with smooth and thin-walled cells, such as $K$. flaccidum (Rindi et al., 2008), this effect was even more pronounced. In contrast, for unicellular algae with thick walls, Guillitte and Dreesen (1995) suggested a preference to attach to a smooth surface by a "suction-cup" phenomenon. As a result, the biological colonization extends more widely over the surface with an abundance of algae retained.

The carbonation, by decreasing surface $\mathrm{pH}$, remarkably accelerated biofouling. The inhibition effect of high surface $\mathrm{pH}$ for algal colonization on stone was also underlined by Prieto and Silva (2005). Unlike the roughness, which impacted upon the ability of algae to physically cling to the surface, the carbonation affected the algal metabolism. Indeed, the alga Klebsormidium is well known as an acidophilic microorganism (Sabater et al., 2003; Novis, 2006; Valente and Gomes, 2007). But, in our tests, they were found in a more or less alkaline medium and so under more or less stressful conditions.

The difference of colonization was thus related to the algae's ability to attach and spread on the surface rather than to the algal concentration in the suspension. This idea is reinforced by the same fluorescence intensity of algae suspension in the two tests, carbonated 
or not (Fig. 10). In the present work, algae grow about three times faster on the carbonated samples than on the uncarbonated ones.

\section{Conclusions}

The test chamber simulating water runoff was adequate to study the relationship among intrinsic characteristics of materials in relation to biological fouling. The colonization of the samples occurred homogeneously and was very reproducible in the test.

The color measurements gave rise to the inherent color of species involved. In accordance with the algae used in this study, the biological colonization made the surface more and more dark, green, and yellow. After a total colonization of the surface, the color could be aggravated due to the stacking of algae.

The role of porosity was not detected in this study, due to the test conditions. A test with alternating cycles of wetting/drying mortar samples should be considered in order to study this parameter.

The laboratory test confirmed the implication of roughness on the biofouling rate. When a lot of anchorage points are offered, the adherence of algae is promoted. Thus the latency time is shortened and the rate of colonization is increased. Particular attention has to be paid to the surface finish of the facade: A slight increase in roughness might abruptly increase the susceptibility to colonization by microorganisms.

The surface $\mathrm{pH}$ proved to be one of the most decisive parameters in determining the material bioreceptivity. A decrease in surface $\mathrm{pH}$ by carbonation promoted algal development significantly, with colonization beginning much earlier and happening much faster. A study on mortar components centered on maintaining a high $\mathrm{pH}$ by preventing carbonation should be considered. 
Extrapolation of the results obtained under accelerated laboratory conditions to the real condition in the nature needs to be ascertained. The next investigative step is to extrapolate these results, obtained under accelerated laboratory conditions, to real-world, natural conditions, with in-situ research. 


\section{References}

Ariño, X., Gomez-Bolea, A., Saiz-Jimenez, C., 1997. Lichens on ancient mortar. International Biodeterioration and Biodegradation 40, 217-224.

Babichenko, S., Leeben, A., Poryvkina, L, 2001. Variability of Chlorella sp. fluorescence in reponse to different nitrogen conditions. International Journal of Remote Sensing 22, 403-414.

Barberousse, H., 2006. Etude de la diversité des algues et des cyanobactéries colonisant les revêtements de façade en France et recherche des facteurs favorisant leur implantation, PhD thesis, Muséum National d'Histoire Naturelle, Paris, France.

Chevalier, B., Chevalier, J.L., 1991. Caractérisation optique des enduits de façade : Influence de la teinte et de la rugosité sur la température atteinte au soleil. Cahiers du CSTB.

Crispim, C.A., Gaylarde, P.M., Gaylarde, C.C., 2003. Algal and cyanobacterial biofilms on calcareous historic buildings. Current Microbiology 46, 79-82.

Darlington, A., 1981. Ecology of walls. Heineman, London.

De Muynck, W., Ramirez, A.M., Belie, N.D., Verstraete, W., 2009. Evaluation of strategies to prevent algal fouling on white architectural and cellular concrete. International Biodeterioration and Biodegradation 63, 679-689.

Deruelle, S., 1991. Rôle du support dans la croissance des microorganismes. Materials and Structures 24, 163-168.

Dubosc, A., Escadeillas, G., Blanc, P.J., 2001. Characterization of biological stains on external concrete walls and influence of concrete as underlying material. Cement and Concrete Research 31, 1613-1617. 
Escadeillas, G., Bertron, A., Blanc, P., Dubosc, A., 2007. Accelerated testing of biological stain growth on external concrete walls. Part 1: Development on the growth tests. Materials and Structures 40, 1061-1071.

Gadelmawla, E.S., Koura, M.M., Maksoud, T.M.A., Elewa, I.M., Soliman, H.H., 2002. Roughness parameters. Journal of Materials Processing Technology 123, 133-145.

Grant, C., 1982. Fouling of terrestrial substrates by algae and implications for control - a review. International Biodeterioration Bulletin 18, 57-65.

Grant, C., Bravery, A.F., 1985. A new method for assessing the resistance of stone to algal disfigurement and the efficacy of chemical inhibitors. Proceedings of the Vth International Congress on Deterioration and Conservation of Stone, Presses Polytechniques Romandes, Lausanne, pp. 663-674.

Grossi, C.M., Esbert, R.M., Díaz-Pache, F., Alons, F.J., 2003. Soiling of building stones in urban environments. Building and Environment 38, 147-159.

Guillitte, O., 1995. Bioreceptivity: A new conception for building ecology studies. The Science of the Total Environment 167, 215-220.

Guillitte, O., Dreesen, R., 1995. Laboratory chamber studies and petrographical analysis as bioreceptivity assessment tools of building materials. Science of the Total Environment $167,365-374$.

Hendry, A.W., 2001. Masonry walls: materials and construction. Construction and Building Materials 15, 323-330.

John, D.M., 1988. Algal growth on buildings: A general review and methods of treatment. Biodeterioration Abstracts 2, 81-102.

Joshi, C.D., Mukunda, U., 1997. Algal disfigurement and degradation of architectural paints in India. Paintindia 47, 27-32. 
Le Borgne, A., Lanos, C., Trigalleau, M., 1994. Le bâtiment face à sa microflore. Editions ARIA/INSA, Reims.

Lokhorst, G.M., 1996. Comparative Taxonomic Studies on the Genus Klebsormidium (Charophyceae) in Europe, Cryptogamic Studies, Vol. 5, Gustav Fischer, Stuttgart, Germany.

Miller, A., Dionísio, A., Macedo, M.F., 2006. Primary bioreceptivity: A comparative study of different Portuguese lithotypes. International Biodeterioration and Biodegradation 57, 136-142.

Miller, A.Z., Dionísio, A., Laiz, L., Macedo, M.F., Saiz-Jimenez, C., 2009. The influence of inherent properties of building limestones on their bioreceptivity to phototrophic microorganisms. Annals of Microbiology 59, 705-713.

Naessens M., Leclerc, J.C., Tran-Minh, C., 2000. Fiber optic biosensor using Chlorella vulgaris for determination of toxic compounds. Ecotoxicology and Environmental Safety $46,181-185$.

Novis, P.M., 2006. Taxonomy of Klebsormidium (Klebsormidiales, Charophyceae) in New Zealand streams and the significance of low-pH habitats. Phycologia 45, 293-301.

Ohshima, A., Matsui, I., Yuasa, N., Henmi, Y., 1999. A study on growth of fungus and algae on mortar. Transactions of the Japan Concrete Institute 21, 173-178.

Ortega-Calvo, J.J., Ariño, X., Hernandez-Marine, M., Saiz-Jimenez, C., 1995. Factors affecting the weathering and colonization of monuments by phototrophic microorganisms. Science of The Total Environment 167, 329-341.

Pietrini, A.M., Ricci, M., Bartolini, M., Giuliani, M.R., 1985. A reddish colour alteration caused by algae on stoneworks. Proceedings of the Vth international congress on deterioration and conservation of stone, Presses Polytechniques Romandes, Lausanne, 653-662. 
Pratt, W. K., 2001. Digital Image Processing, $3^{\text {rd }}$ Edition, John Wiley \& Sons, Inc, New York. Prieto, B., Silva, B., 2005. Estimation of the potential bioreceptivity of granitic rocks from their intrinsic properties. International Biodeterioration and Biodegradaton 56, 206-215.

Pourchez, J., Ruot, B., Debayle, J., Pourchez, E., Grosseau, P., 2010. Some aspects of cellulose ethers influence on water transport and porous structure of cement-based materials. Cement and Concrete Research 40, 242-252.

Rindi, F., Guiry, M.D., López-Bautista, J.M., 2008. Distribution, morphology, and phylogeny of Klebsormidium (Klebsormidiales, Charophyceae) in urban environments in Europe. Journal of Phycology 44, 1529-1540.

Sabater, S., Buchaca, T., Cambra, J., Catalan, J., Guasch, H., Ivorra, N., Muñoz, I., Navarro, E., Real, M., Romaní, A., 2003. Structure and function of benthic algal communities in an extremely acid river. Journal of Phycology 39, 481-489.

Saiz-Jimenez, C., 1995. Deposition of anthropogenic compounds on monuments and their effect on airborne microorganisms. Aerobiologia 11, 161-175

Shirakawa, M.A., Beech, I.B., Tapper, R., Cincotto, M.A., Gambale, W., 2003. The development of a method to evaluate bioreceptivity of indoor mortar plastering to fungal growth. International Biodeterioration and Biodegradation 51, 83-92.

Škaloud, P., 2006. Variation and taxonomic significance of some morphological features in european strains of Klebsormidium (Klebsormidiophyceae, Streptophyta). Nova Hedwigia 83, 533-550.

SNMI, 2010. Syndicat National des Mortiers Industriels. www.snmi.org.

Tomaselli, L., Lamenti, G., Bosco, M., Tiano, P., 2000. Biodiversity of photosynthetic microorganisms dwelling on stone monuments. International Biodeterioration and Biodegradation 46, 251-258. 
Valente, T.M., Gomes, C.L., 2007. The role of two acidophilic algae as ecological indicators of acid mine drainage sites. Journal of Iberian Geology 33, 283-294.

Wee, Y.C., Lee K.B., 1980. Proliferation of algae on surfaces of buildings in Singapore. International Biodeterioration Bulletin 16, 113-117.

Wessel, D., 2011. Case Study: Field observations on the effectiveness of zinc strips. In: Charola, A.E., McNamara, C., and Koestler, R.J., (Eds.), Biocolonization of Stone: Control and Preventive Methods: Proceedings from the MCI Workshop Series, Smithsonian Contributions to Museum Conservation: 2, Washington, DC: Smithsonian Institution Scholarly Press, pp. 109-112.

Young, M.E., 1997. Biological growth and their relationship to the physical and chemical characteristics of sandstones before and after cleaning, $\mathrm{PhD}$ thesis, The Robert Gordon University, Aberdeen, Scotland. 
Table 1

Mortar formulation

\begin{tabular}{ccccc}
\hline Component & Cement & Sand & $\begin{array}{c}\text { Calcareous } \\
\text { Filler }\end{array}$ & $\begin{array}{c}\text { Admixture }^{\mathrm{a}} \\
\text { (in the case of } w / c=1 \text { ) }\end{array}$ \\
\hline$\%$ mass of dry mixture & 30 & 65 & 5 & 0.27 \\
\hline
\end{tabular}

${ }^{\mathrm{a}}$ in addition to dry mixture (cement, sand and filler)

Table 2

Porosity and surface $\mathrm{pH}$ of the mortars

\begin{tabular}{ccccc}
\hline Ratio $w / c$ & & Code & Porosity (\%) & Surface pH \\
\hline 0.5 & Uncarbonated & 05UC & $15.9 \pm 0.6$ & $11.2 \pm 0.4$ \\
& Carbonated & 05C & $10.6 \pm 0.4$ & $9.5 \pm 0.2$ \\
\multirow{2}{*}{1.0} & Uncarbonated & 10UC & $37.2 \pm 0$ & $11 \pm 0.4$ \\
& Carbonated & 10C & $32.1 \pm 1.9$ & $9.0 \pm 0.1$ \\
\hline
\end{tabular}

Table 3

Roughness of the mortars

\begin{tabular}{clcccc}
\hline & & $\mathrm{Code}$ & $\mathrm{R}_{\mathrm{a}}(\mu \mathrm{m})$ & $\mathrm{R}_{\mathrm{p}}(\mu \mathrm{m})$ & $\mathrm{R}_{\mathrm{v}}(\mu \mathrm{m})$ \\
\hline \multirow{3}{*}{ Uncarbonated } & Roughness 1 & $\mathrm{R} 1$ & $29 \pm 5$ & 92 & 43 \\
\cline { 2 - 6 } & Roughness 2 & $\mathrm{R} 2$ & $55 \pm 4$ & 243 & 226 \\
\cline { 2 - 6 } Carbonated & Roughness 3 & $\mathrm{R} 3$ & $123 \pm 9$ & 845 & 1188 \\
\cline { 2 - 6 } & Roughness 1 & $\mathrm{R} 1$ & $30 \pm 3$ & 82 & 50 \\
\cline { 2 - 6 } & Roughness 2 & $\mathrm{R} 2$ & $55 \pm 4$ & 243 & 226 \\
\cline { 2 - 6 } & Roughness 3 & $\mathrm{R} 3$ & $169 \pm 17$ & 820 & 1360 \\
\hline
\end{tabular}


a)

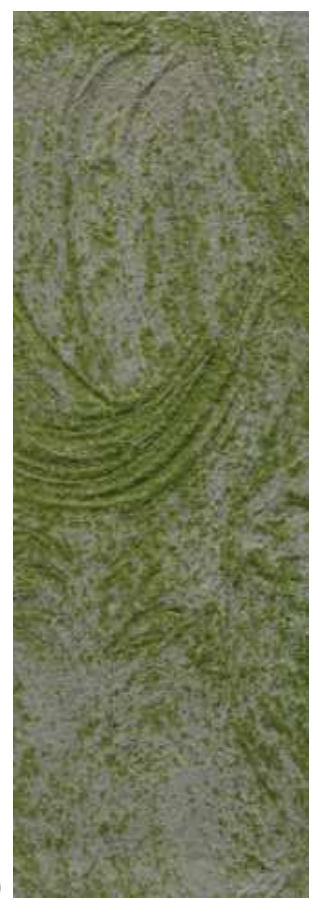

b)

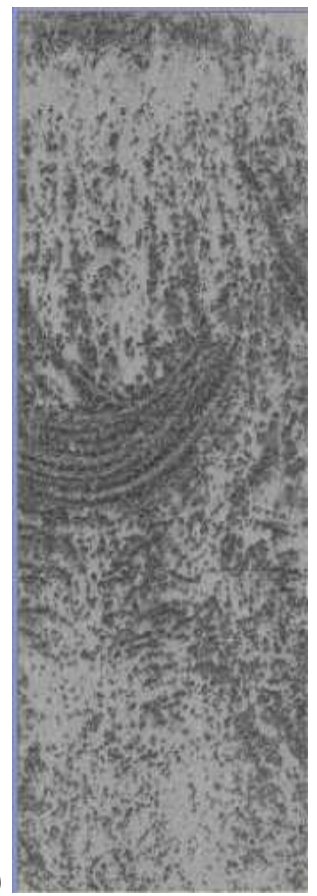

c)

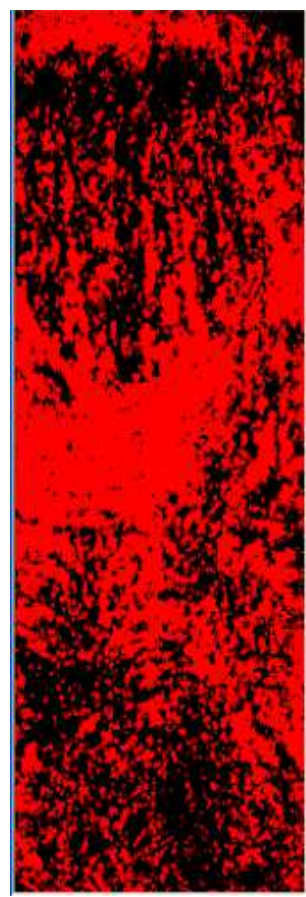

Fig. 1 Example of image analysis of a specimen after 17 days of test a): original picture obtained by the scanner;

b): $Q$ band after the conversion of image a) in $Y I Q$ color space;

c): image obtained from image b) after a segmentation by a threshold. 

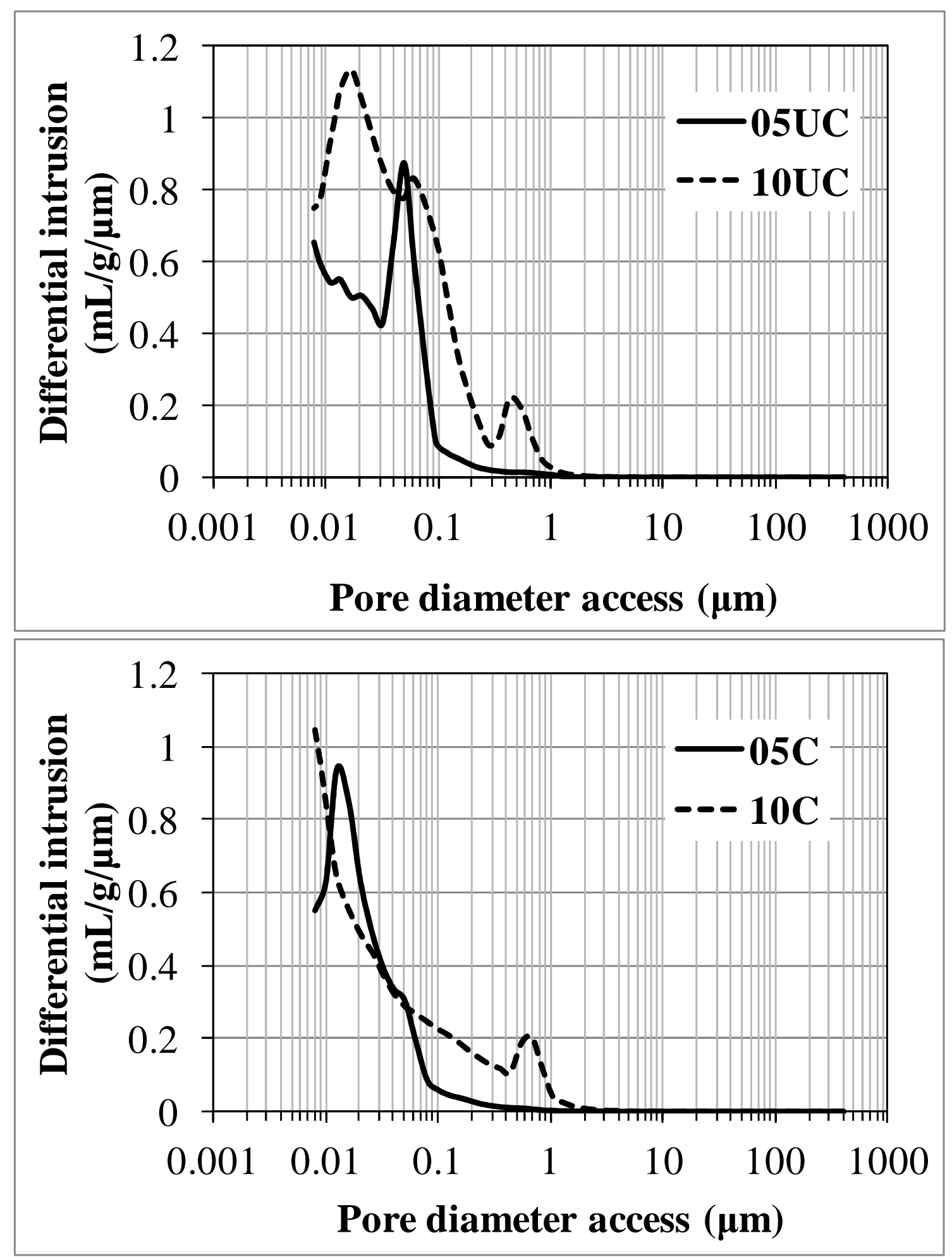

Fig. 2 Pore size distribution of uncarbonated (UC) and carbonated (C) mortars with a $w / c$ ratio of 0.5 and 1 


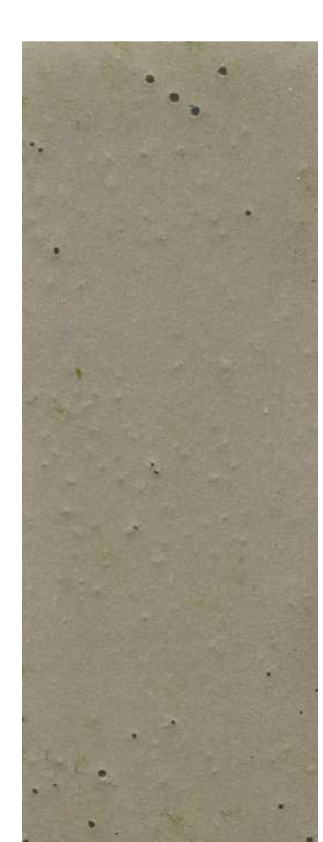

1 day

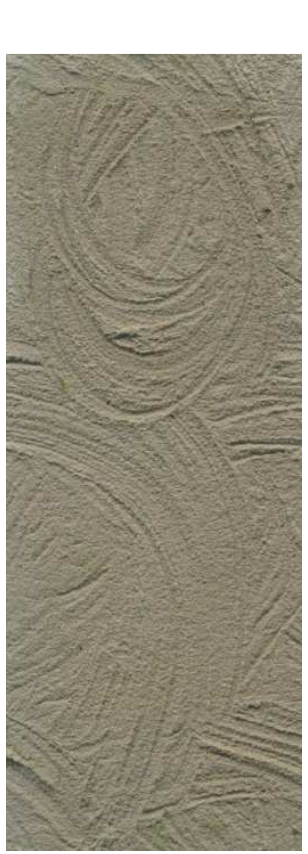

1 day

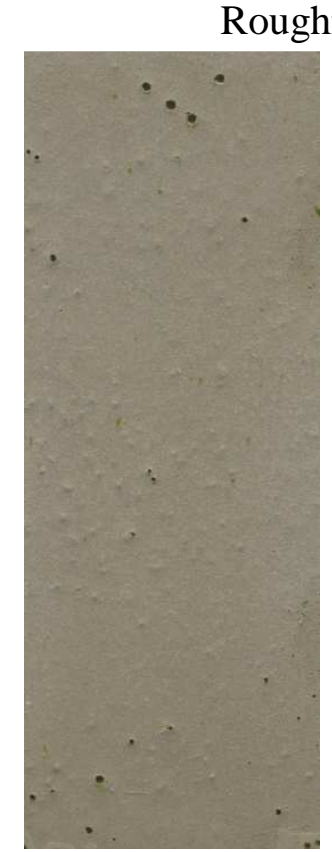

11 days

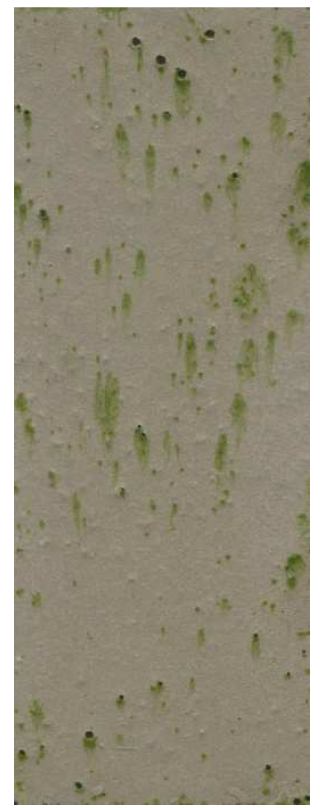

19 days

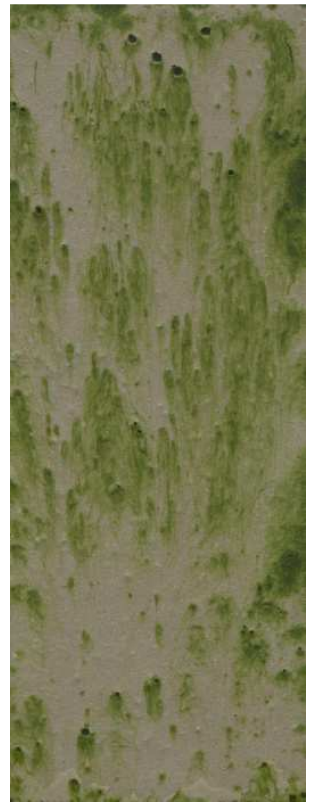

25 days

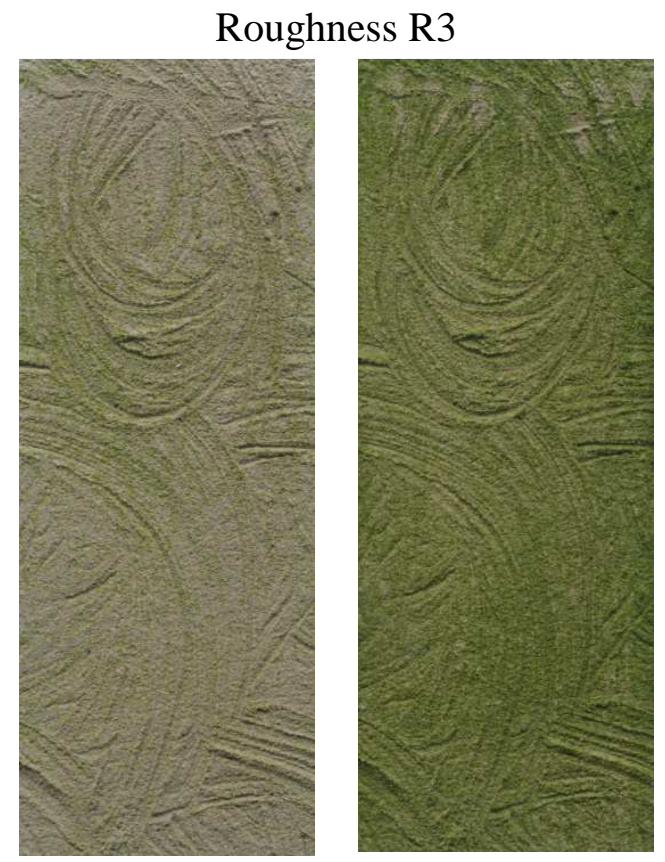

19 days

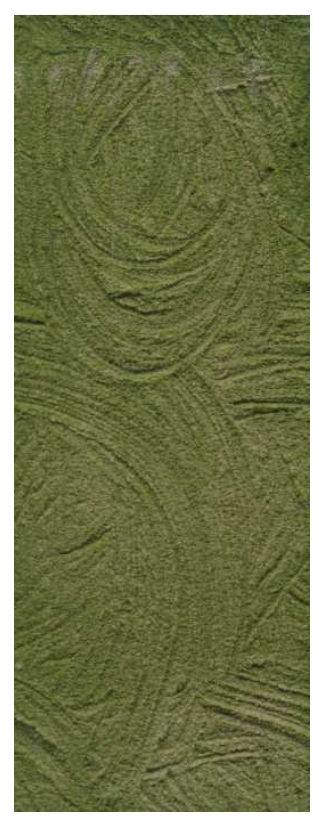

25 days

Fig. 3 Surface colonized by algae with time of carbonated mortars $(w / c$ ratio 1$)$ with roughnesses R1 and R3 


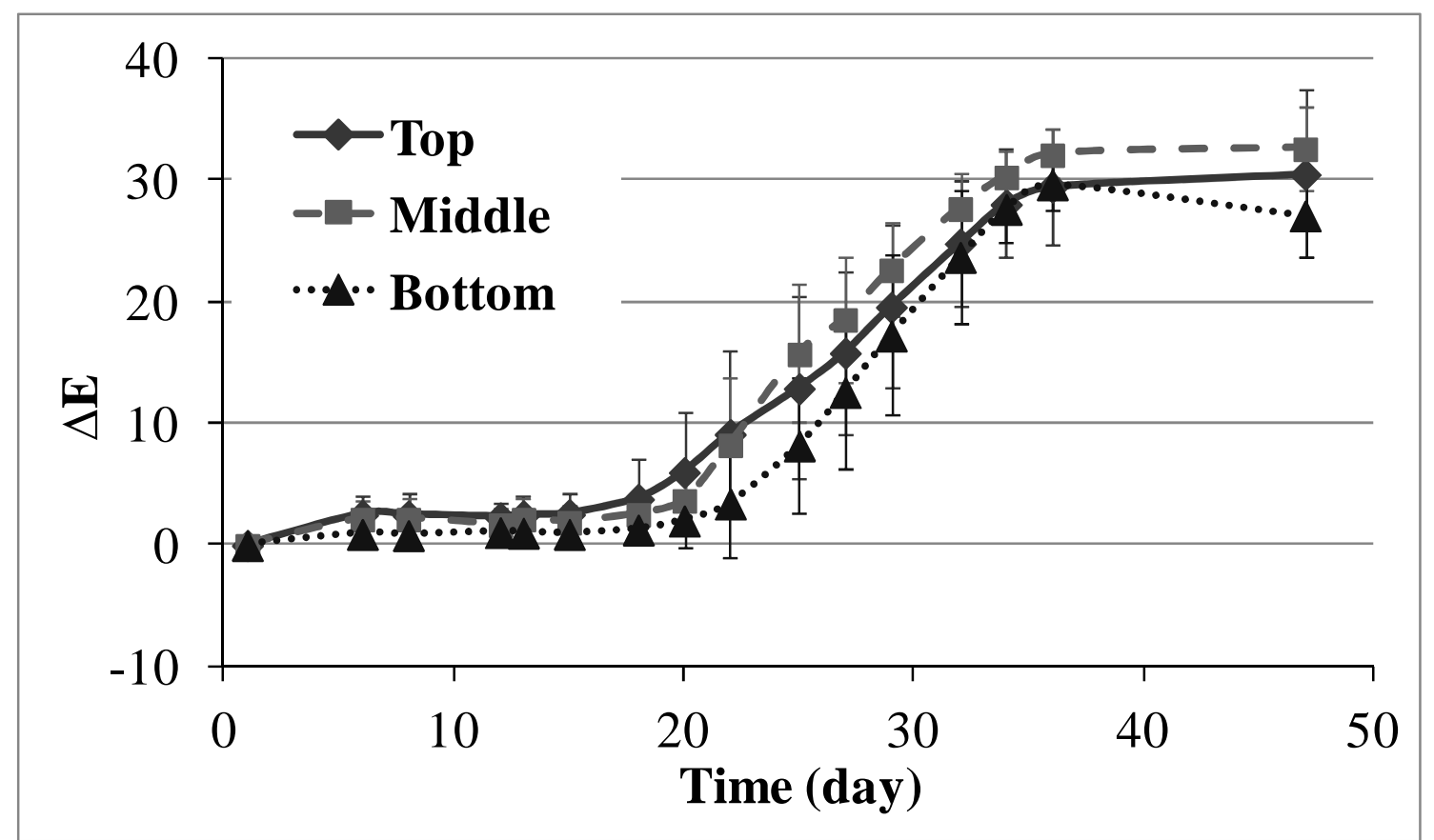

Longitude direction

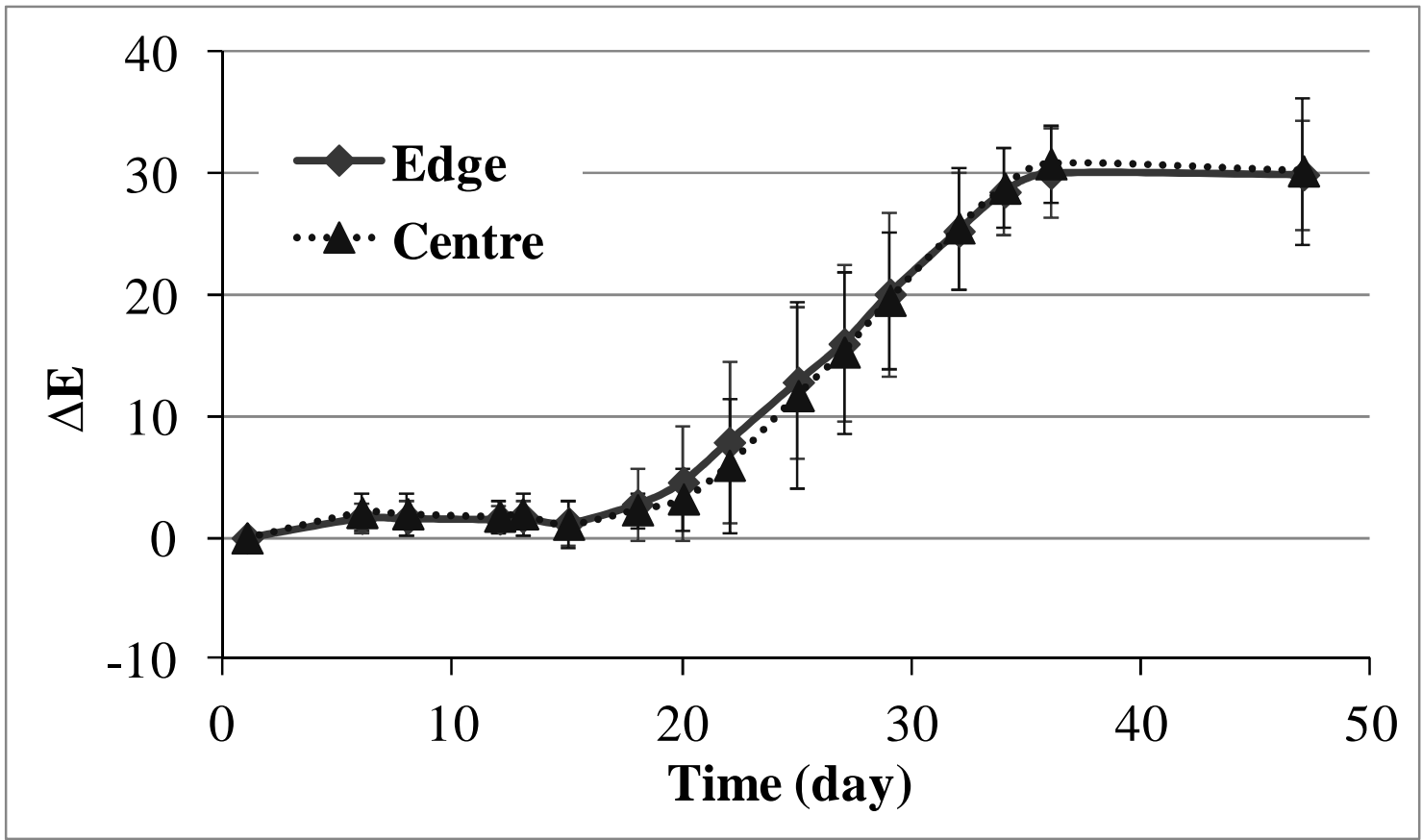

Transverse direction

Fig. 4 Change of $\Delta E$ versus time in different parts of sample 10C-R1 during accelerated fouling test 


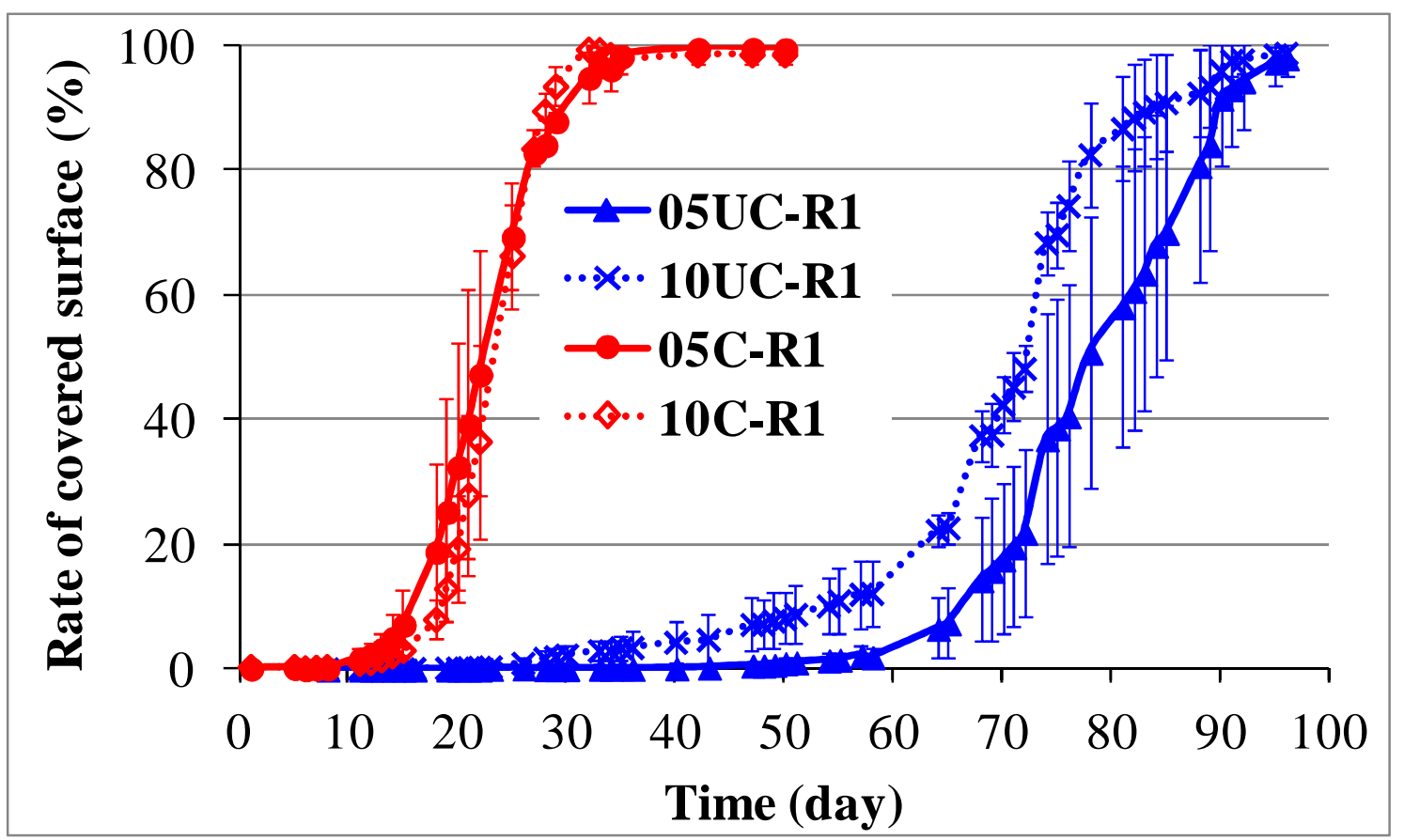

Fig. 5 Effect of $w / c$ ratio (0.5 and 1) on covered area versus time of uncarbonated (UC) and carbonated (C) mortars, of roughness R1 

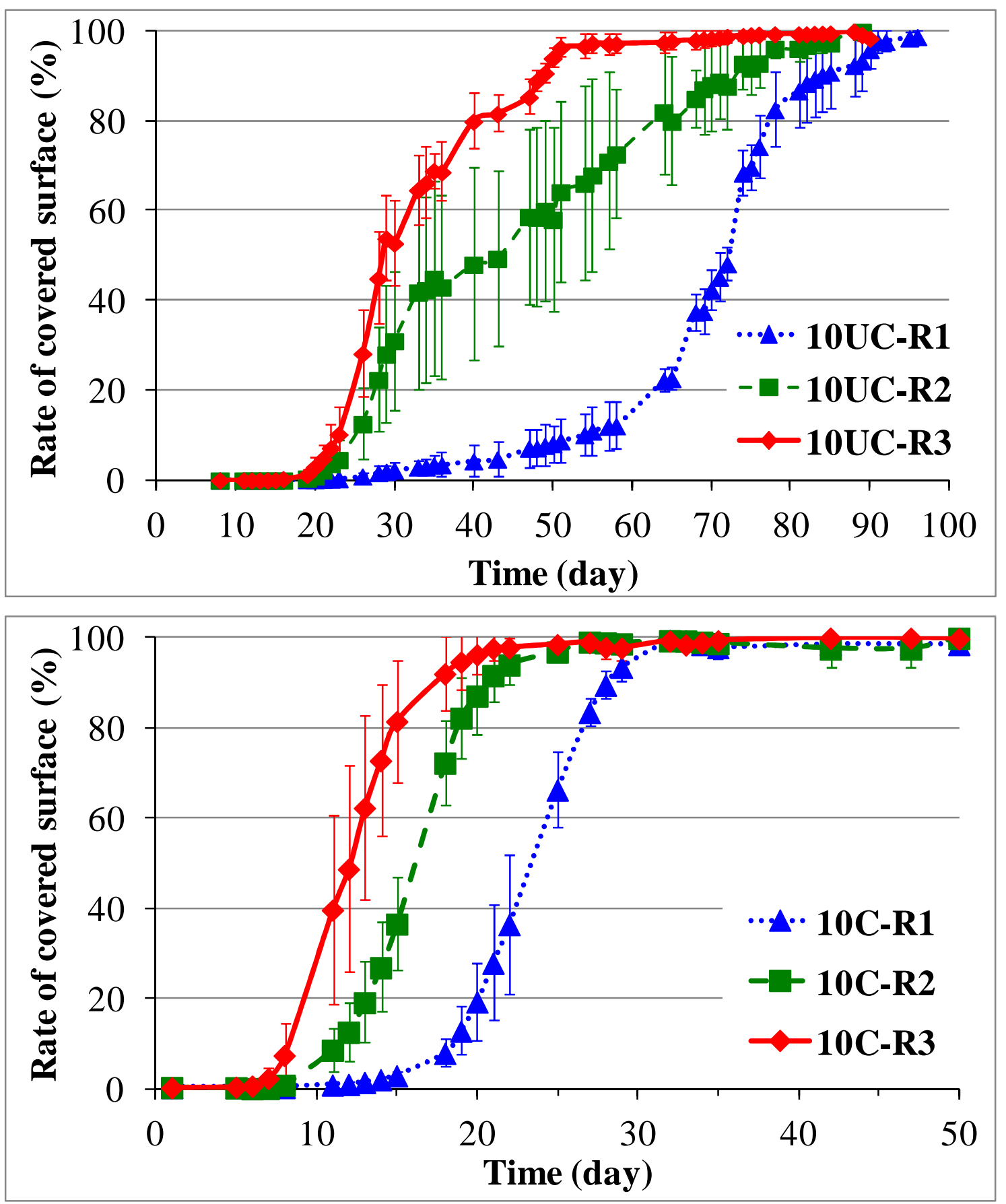

Fig. 6 Influence of roughness on covered area versus time of uncarbonated (UC) and carbonated (C) mortars mixed with a $w / c$ ratio of 1 


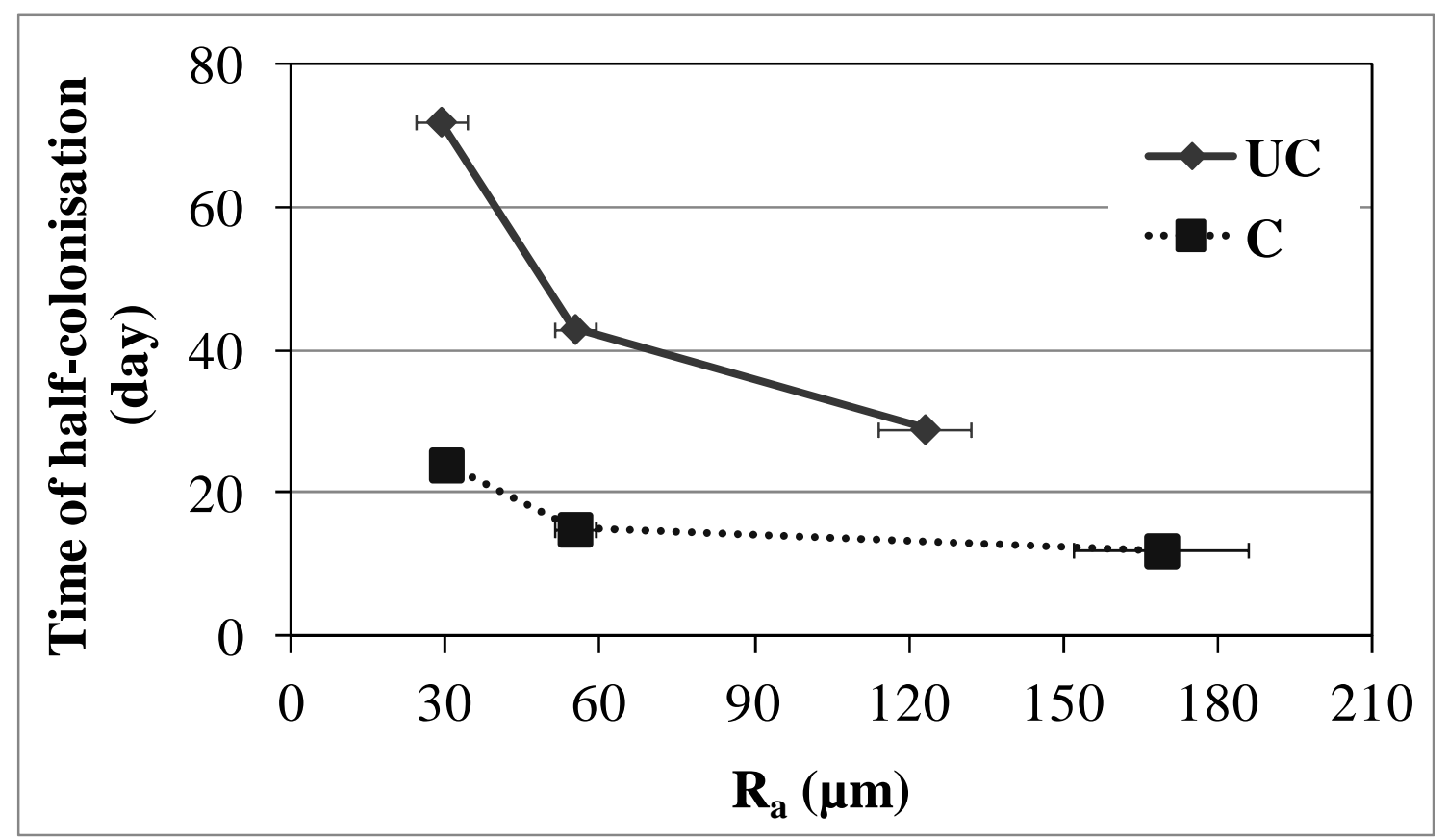

Fig. 7 Evolution of time of half-colonization versus roughness $\left(\mathrm{R}_{\mathrm{a}}\right)$ 


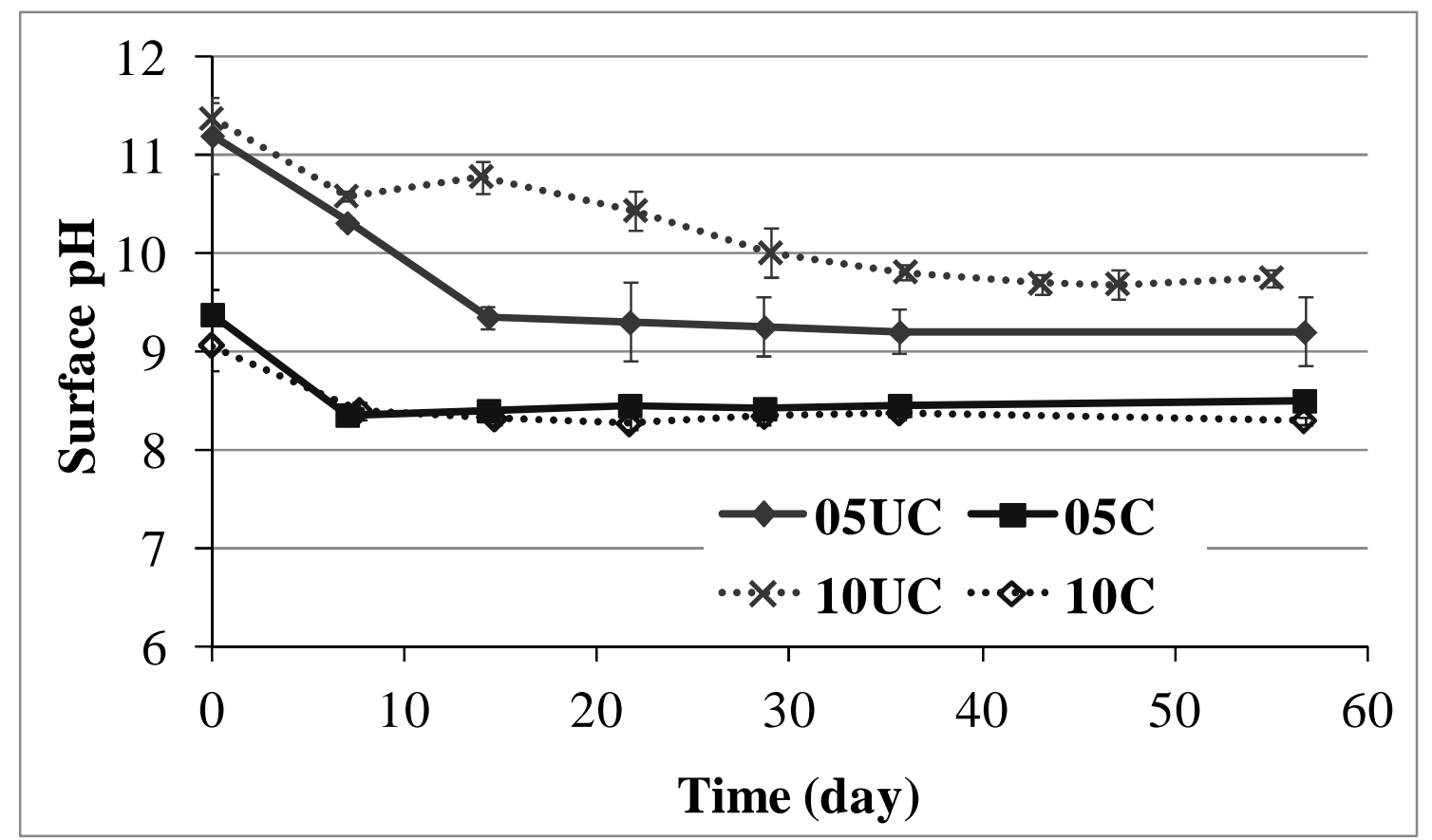

Fig. 8 Surface pH of uncarbonated and carbonated mortars mixed with a $w / c$ ratio of 0.5 and 1 during the accelerated fouling test 


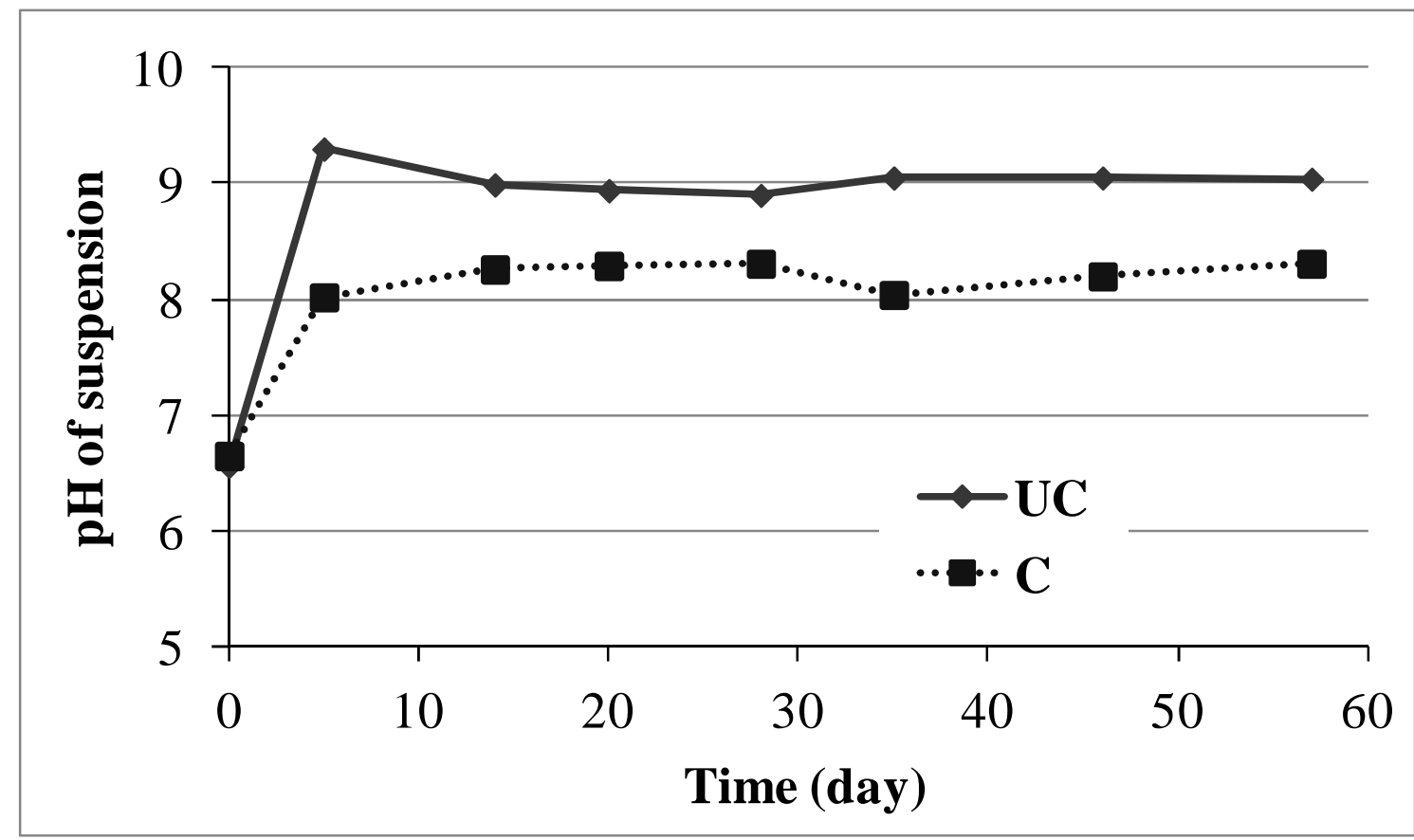

Fig. $9 \mathrm{pH}$ suspension for uncarbonated and carbonated samples during the accelerated fouling test 


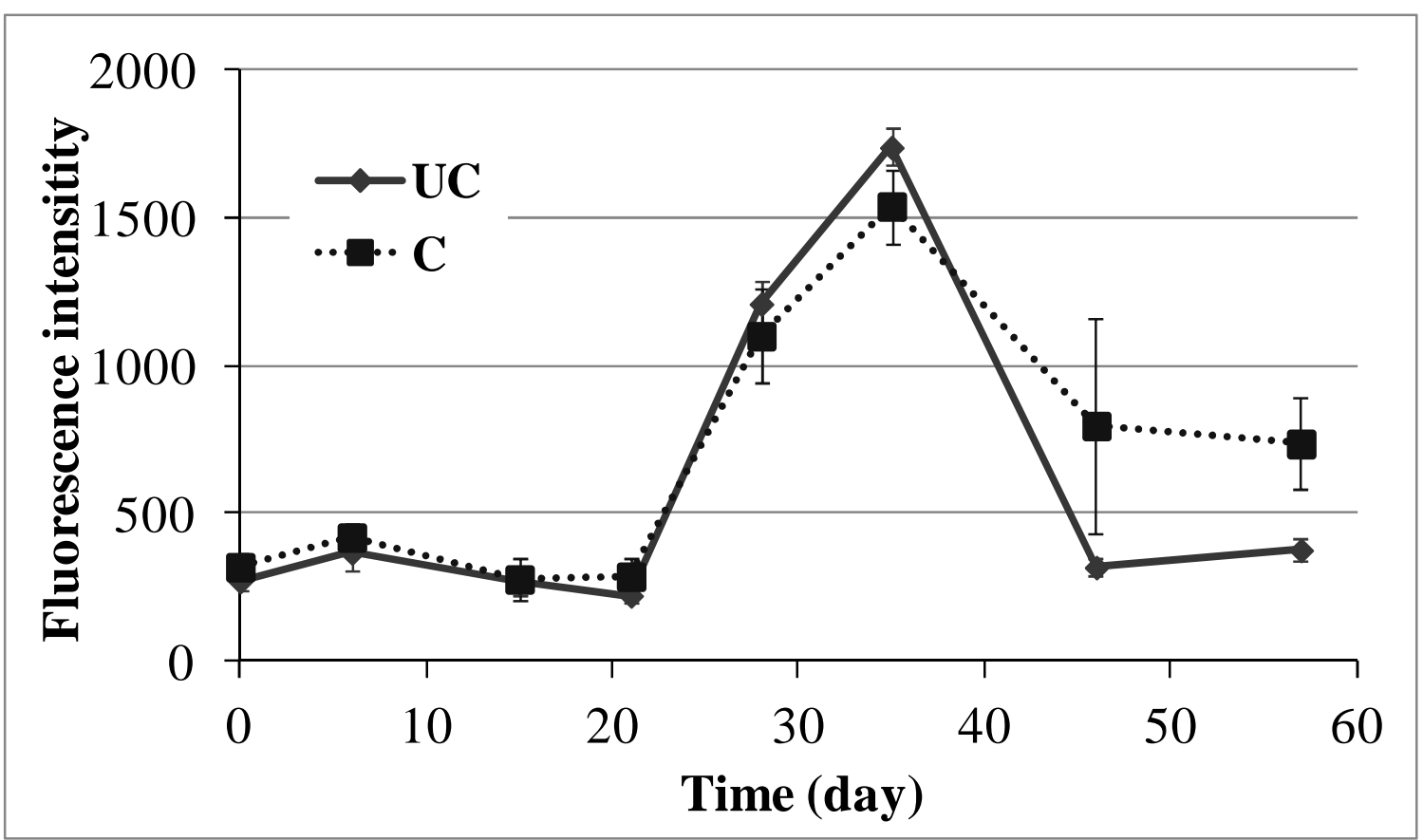

Fig. 10 Fluorescence intensity of the algae suspension for uncarbonated and carbonated samples during the accelerated fouling test 